\title{
Civic stratification and crime. A comparison of asylum migrants with different legal statuses
}

\author{
Arjen Leerkes $^{1}$ (D) $\cdot$ Godfried Engbersen $^{1} \cdot$ Erik Snel $^{1}$ • \\ Jan de Boom ${ }^{2}$
}

Published online: 21 November 2017

(C) The Author(s) 2017. This article is an open access publication

\begin{abstract}
Contrary to natural born citizens, migrants can have a variety of legal statuses depending on how they are classified by immigration law. Together, such legal or 'civic' statuses constitute a system of civic stratification, from high (privileged) to low (restricted). Recent scholarship highlights the relevance of immigration law for understanding crime patterns. We analytically synthesize this literature and extend it empirically by examining its usefulness in explaining the relationship between asylum migrants' civic statuses in The Netherlands and their chances of being registered as a crime suspect. Logistic regression analyses were conducted using a unique dataset in which comprehensive administrative data from various governmental sources were combined. Four civic status groups were compared: naturalized citizens, residence permit holders, asylum seekers in the procedure, and former asylum seekers whose stay in the country had become unauthorized. The results suggest that strain theory and more constructionist stances are required in order to understand the complex relationship between civic stratification and crime. We discuss implications for other countries.
\end{abstract}

\section{Introduction}

Immigration law defines the degree to which different categories of international migrants are incorporated into destination countries. As a consequence, and contrary

Arjen Leerkes

leerkes@essb.eur.nl

1 Department of Public Administration and Sociology, Erasmus University Rotterdam, Burgemeester Oudlaan 50, 3062 PA Rotterdam, The Netherlands

2 Rotterdam Institute for Social Policy Research (RISBO), Erasmus University Rotterdam, Burgemeester Oudlaan 50, 3062 PA Rotterdam, The Netherlands 
to natural-born citizens, immigrants can have a variety of administrative or legal statuses (hereafter called: 'civic statuses'). Among asylum migrants, for example, we find naturalized citizens, residence permit holders, those who are 'in the procedure' (i.e., have temporary legal stay without a residence permit), and unauthorized immigrants. Each of these statuses affords, or denies, specific social, economic and political rights. The term 'civic stratification' refers to such systems of differentiated rights [1-5].

Recent scholarship on immigration and crime highlights the significance of immigration law for understanding crime patterns. Within this emerging approach there are two main perspectives. The first views the differentiation of civic statuses as a potential ultimate cause of differences in criminal behavior [6-12]. Here, the central assumption is that an individual's civic status influences the degree to which (s)he is being exposed to social conditions that produce, or prevent, offending. For instance, having a marginal civic status may result in relative deprivation and strain, and may indirectly trigger certain forms of crime.

The second perspective does not attribute a causal role to civic status, but argues that the possible relationship between civic status and crime is due to various forms of social sorting in the allocation of civic statuses, and in the definition of what counts as a crime [9, 11-19]. First, in the regulation of international migration there is a tendency to channel migrants who are believed to represent a threat to public safety, including migrants with a known or suspected criminal history, into the lower statuses, while the higher statuses are reserved for migrants who are not believed to pose a risk to society. Naturalization, for instance, often requires a (relatively) clean criminal record. Here, differences in offending produce differences in civic status rather than the other way around. Second, civil servants and immigration judges may, whether consciously or not, contribute to a spurious relationship between civic status and crime by putting certain categories of immigrants with greater chances of offending at a disadvantage when making admission decisions. For example, young single males seem to have less chance of obtaining an asylum residence permit than females and males in families, because they are more likely to be seen as fortune seekers abusing the asylum procedure [20]. A third form of selectivity, which is situated at the intersection of immigration law and criminal law, is selective criminalization. States are increasingly criminalizing migration-related behavior among 'unwanted' immigrants. In several countries, for example, being an unauthorized immigrant is a crime in and of itself.

So far, the two perspectives have proved useful to explain crime patterns among unauthorized immigrants. This article makes two main contributions: (1) it analytically synthesizes the emerging literature, and (2) it extends it empirically by investigating how a state's regulation of international migration influences the crime patterns among migrants with a wider number of civic statuses. In this article, we use administrative and police data to study (registered) criminal activity among immigrants with a history as asylum seeker. Asylum migrants constitute a strategic research group to study the relationship between civic stratification and crime, as the asylum population is even more differentiated with respect to civic status than other types of migrants. While other migrants generally have to await the result of admission decisions outside of the state's territory before they being allowed to enter for any length of time, asylum seekers already have legal stay, but few rights, while their application for an asylum residence permit is being processed.

The analysis is based on a large and unique dataset on all first-generation immigrants who applied for asylum in The Netherlands in the period 1995-2004. It was 
constructed in 2005 as part of a research project for the Dutch Police \& Science Program (see [21]). Two research questions guided the analysis: (1) Is there any relationship between asylum migrants' civic status in The Netherlands and their chance of being registered as a crime suspect? (2) Can that relationship be explained by the two perspectives outlined above?

In the next section, we elaborate the notion of civic stratification, and describe the main civic statuses among asylum migrants in The Netherlands. Next, we conceptualize the relationship between civic status and crime, and report the data sources, method and findings. The concluding section discusses recent changes in Dutch immigration policies and goes into the findings' generalizability for other countries.

\section{Civic stratification and the Dutch asylum procedure}

The term 'civic stratification' has been coined by Lockwood [2], who raised the question of whether the function of citizenship to promote social integration in the polity - a central idea in Marshall's sociology of rights - is threatened by tendencies toward civic stratification, either because of inequality in de jure entitlement to rights or in the de facto access to rights. In his view, civic stratification takes place along two axes: (1) differences in citizenship rights and (2) differences in moral and material resources. Four ideal-typical positions can therefore be identified. On top of the hierarchy are those who have full rights and have the resources to access them ('civic gain'). At the bottom are those who are denied rights and lack the resources to eventually expand them ('civic exclusion'). In between, there are those who are formally entitled to rights, yet who lack the resources to make use of them ('civic deficit'), and those who are not entitled to certain rights, yet who do possess the moral and material resources to obtain them in the future ('civic expansion').

Migration researchers began using the concept in order to describe the complex hierarchy of immigrants' legal statuses [1, 3-5, 22]. Their focus has been on the formal aspects of civic stratification, i.e., differential entitlement to rights. This is, for example, how Morris ([3], p. 20-21) has applied the idea of differentiated membership in the polity to asylum migrants:

"Recognized refugees are usually granted unlimited residence, while other asylum seekers may receive humanitarian leave for a specified period. There are also asylum seekers whose cases are pending and, finally, migrants present in an unlawful status, having either crossed borders undetected or exceeded their permitted period of stay. (...) Full refugee status carries with it social rights, family reunification rights and access to the national, but not the EU, labor market. (...) Asylum seekers whose status is pending are much more precariously placed - they generally have reduced social rights and are sometimes, it can be argued, denied their civil rights, if held in detention until their case has been considered".

Such tendencies toward stratification are assumed to be due to states trying to manage conflicting interests (cf. Hollifield's [23] 'liberal paradox'). On the one hand, 
there is a need and willingness to incorporate certain categories of immigrants, including 'genuine' refugees. Ideals of egalitarianism entail the idea that such newcomers should, within a reasonable period of time, be treated as full and equal members of the society, and a path to full citizenship is provided. On the other hand, the relative openness of liberal societies creates strong tendencies to limit 'unwanted' migration, and that goal is believed to be obtained, at least in part, by reducing such migrants' access to labor markets and social provisions. Paying attention to civic stratification as a relatively new aspect of social stratification has proven to be crucial for understanding a host of phenomena in which social scientists take an interest, such as individual's social networks [24], second-generation educational outcomes [25], criminal proceedings [26], and occupational status [27].

In this article, we use the term 'civic status' as a specific, i.e., to indicate that a person has a particular civic status (such as: 'naturalized citizen'), and as a generic, i.e., to indicate that in contemporary societies all individuals are attributed a legal status that defines their formal membership in the nation. As a generic, civic status can be conceptualized as an ordinal variable, i.e., as a variable with values that can be ordered in terms of 'high' (privileged) and 'low' (restricted). The focus is on the four main statuses among asylum migrants: (1) naturalized asylum migrants, (2) asylum migrants with a residence permit, (3) asylum seekers in procedure, and (4) unauthorized immigrants. By distinguishing four main statuses, we simplify to some extent; there is actually some differentiation within these main statuses. ${ }^{1}$

The highest position in the Dutch civic hierarchy is occupied by admitted asylum migrants who have become Dutch citizens through naturalization. They have full social, economic and political rights, including full access to the labor market and public provisions, such as public housing and welfare. Naturalization requires, among other things, at least five years of consecutive legal stay on the basis of a residence permit and - crucial for the present analysis - four consecutive years without having been sentenced to incarceration, a community punishment or a major fine. ${ }^{2}$

The second position pertains to residence permit holders. They include those who are recognized as a refugee in the sense of the Geneva Convention, who are given subsidiary protection, or family members who receive what are called dependent asylum permits. Asylum residence permit holders have, in principle, the same social and economic rights as national citizens, but only build up political rights at the municipal level. Compared to native citizens, many naturalized asylum migrants and residence permit holders still live in relatively marginal conditions. A study on admitted asylum migrants from Afghanistan, Iran, Iraq, and Somalia showed that in 2009, depending on the nationality, between $17.6 \%$ and $35.7 \%$ of the (potential) labor force in these groups received welfare, against 1.6\% among the native Dutch ([28], also see [29]). Nevertheless, their average living standard - a regular welfare benefit is about

\footnotetext{
${ }^{1}$ For example, rejected asylum seekers who cannot return to the country of citizenship due to their medical condition may obtain a temporary residence permit that does not give a right to financial support or accommodation, and no right to work. Likewise, some asylum seekers in the procedure no longer have legal stay, because they may no longer await the final outcome of the procedure in The Netherlands. This occurs when an asylum seeker is (i) appealing a rejection in what is called the fast track procedure, (ii) has lost an appeal procedure and starts a higher appeal procedure, or (iii) submits a repeated asylum request after a rejection (without mentioning 'new facts').

${ }^{2}$ Rijkswet op het Nederlanderschap, Article 9.2.
} 
$€ 1300$ a month for a childless couple - was substantially higher than among those with the two remaining civic statuses.

The third main civic status pertains to those who are 'in the procedure', meaning that their case is under consideration. In principle, they can legally stay for the procedure's duration, but they have limited access to the formal labor market and education, and no access to welfare. In the period on which this study focuses, those who were in the procedure for at least six months could work in certain sectors for a maximum of 12 weeks a year. During the procedure, basic needs were provided for by the state in the form of a 'bed, water and bread' arrangement, and a weekly allowance of $€ 55$ per adult (amount for 2005). Under-age children of those in procedure were entitled to free education until their 18th birthday. Those aged 18 or older are entitled to enroll for a study, but cannot receive state grants. There are no figures on labor participation among asylum seekers, but it is assumed to be limited. Employers need to actively seek and receive permission from the state to employ them, and asylum seekers tend to be housed in rural areas with limited labor opportunities. Despite efforts to shorten asylum procedures, a stay in an asylum center can last for years (also because of appeals to negative decisions) (cf. [30]).

Fourth and finally, there are asylum migrants who have exhausted all legal remedies. Once a final negative decision has been reached, asylum seekers are to leave the country within four weeks. Those who stay, become unauthorized. They have no right to work, are not allowed to rent housing, and, barring exceptions, have no access to health services. ${ }^{3}$ Since the early 1990 s, The Netherlands implemented various policies to limit unauthorized immigrants' de facto access to life chances. In 1991, it barred the use of social security numbers for unauthorized immigrants, which severely limited their opportunities to work. In 1994, the Compulsory Identification Act was introduced, which stipulates that people must be able to identify themselves at a place of employment, in case of crimes and misdemeanors and whenever there is a 'concrete suspicion' (since 2001: 'reasonable presumption') of illegal residence. In 1998, the 'Linking Act' was implemented, which excludes unauthorized immigrants from a wide array of public services, including welfare, public housing, education, and (most) health care. The act requires government and semi-government services, such as welfare departments and housing associations, to check whether their clients are legal residents and hence entitled to certain services or benefits. The national government also increasingly allocated resources to enforce employer sanctions.

There is no doubt that unauthorized immigrants are at risk of an extremely marginal position under this policy regime [8], but three main forces still moderate the effects of the exclusionary measures. First, some local governments, churches and NGOs organize poor-relief arrangements in the form of shelter and the occasional provision of living allowances [31]. Women and families with children in particular benefit from these arrangements. Second, some unauthorized migrants receive support from more established immigrants, or from a native Dutch partner. They, too, are under less pressure to turn to criminal offences [8, 32]. Third, some employment opportunities remain on the informal labor market, such as domestic work [33], reducing the pressure to offend.

\footnotetext{
${ }^{3}$ These exceptions are: education for minors, 'medically necessary health care', and legal representation.
} 


\section{Conceptualizing the relationship with crime}

\section{Differential exposure to strain}

The two perspectives sketched in the introduction conceptualize the relationship between civic status and crime differently. According to the first perspective, which we propose to call the 'behavioral perspective', civic status may have an indirect effect on crime (see Fig. 1a), as it determines, at least in part, the extent to which its holders are exposed to, or protected from, social conditions that may generate criminal behavior.

A central assumption underlying the present analysis is that the relationship between civic status and crime cannot be understood without paying attention to strain theory [34, 35]. Due to their privileged civic status, naturalized immigrants and residence permit holders will, on average, experience less relative deprivation than asylum seekers in the procedure, who in turn will experience less relative deprivation than those who have become unauthorized residents. As a consequence, the higher the civic status, the lower the probability of people committing crimes because they lack the conventional means to realize positively valued goals. A second reason to make this central assumption is provided by previous research in The Netherlands, which already found suggestive empirical evidence for a relationship between civic status and crime as a result of differential exposure to strain. For instance, Althoff et al. [7], who conducted in-depth analyses of police files involving asylum seekers, observed that criminal behavior often concerned petty theft (mostly shoplifting) and drug use, and occasional violence against other asylum seekers in the asylum center. They attribute these offences to the frustration that asylum seekers experience as a result of prolonged relative poverty, insecurity about the asylum decision, and restrictions on individual freedom that come with living in an asylum center. Studies on the unauthorized population have similarly concluded that those lacking legal stay are at risk of committing certain crimes in response to the strains of a highly marginal social position $[8,9,17]$. One study specifically conducted repeated in-depth life course interviews with 26 (male) unauthorized immigrants with a criminal record and a history as asylum seeker [32]. While some men admitted to having police contacts in the country of origin, most claimed to have become involved in crime during the asylum procedure, or after becoming unauthorized. Most men did not commit 'survival crime' in the narrow sense - although several were confronted with homelessness and then stole food. Yet, they were sometimes pressed into committing certain crimes in order to meet conventional social standards in difficult living conditions, such as the norm to have your own money and not depend on other people's support too much, to occasionally send money or goods to the family in the country of origin, or to have money for crucial family events such as a wedding or the funeral of a deceased parent. It mostly concerned non-violent, 'innovative' crimes [35], which were primarily aimed at obtaining income and/or reducing deportation risks. Hence, most crimes were classified as 'residence crime' (using false or borrowed papers to enter or leave the country or to pass in-country ID checks) or 'subsistence crime' (shoplifting, car burglary, occasional house burglary, using false or borrowed papers to obtain access to the formal labor market, petty drug dealing). Additionally, a few men became involved in 'drug-related acquisitive crimes' (drug dealing and property crimes to finance drug use). Problematic drug use had often started during long asylum procedures or during illegal residence, usually in conjunction with the strains of homelessness, and sometimes led to more serious forms of offending, including frequent house burglary, in order to finance drug use. 
a)

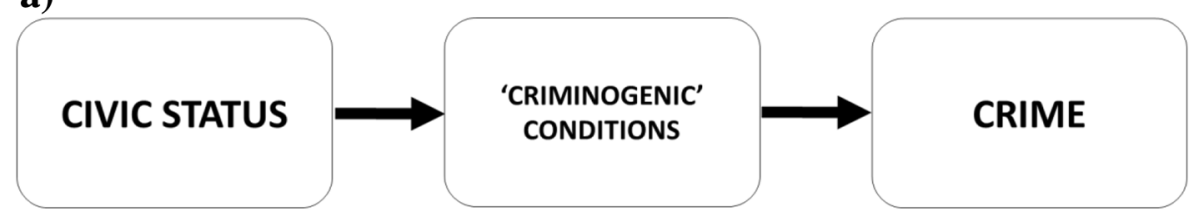

b)

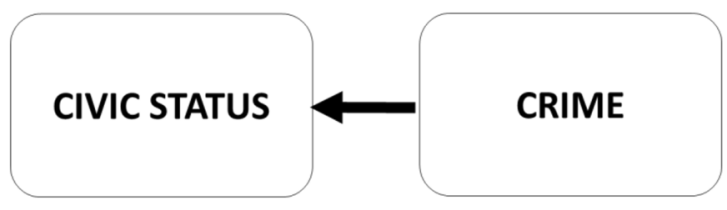

c)

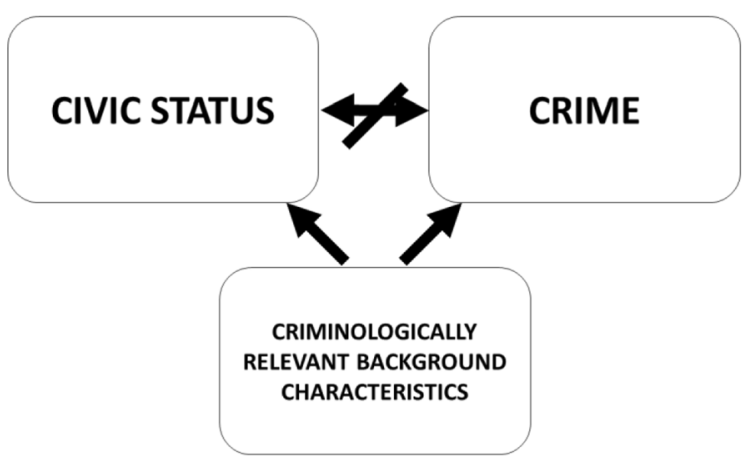

d)

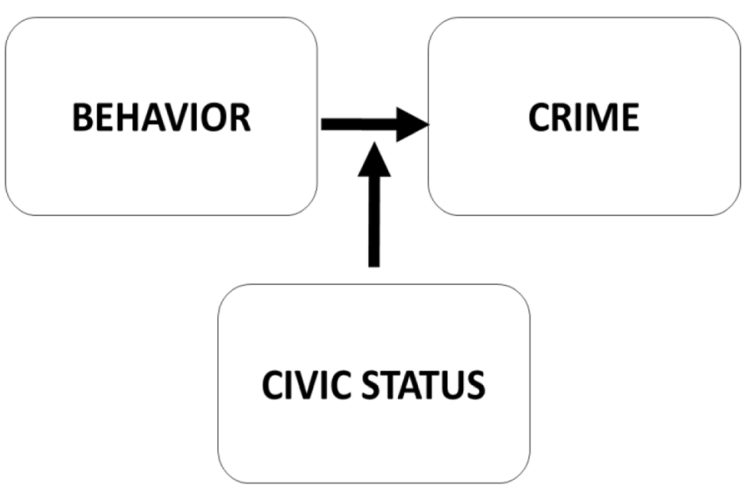

Fig. 1 Conceptualizing the relationship between civic status and crime

The 'lower' one's civic status, the more one is at risk of deportation and/or immigration detention in case of police contacts. These aspects of what it means to have a restricted civic status potentially limit crime involvement (compare Abrego [36] on the legal consciousness of first-generation unauthorized immigrants in the United States). In The Netherlands, however, the effects of differential exposure to strain increasingly began to outweigh the effects of differential exposure to formal social control. While the 
(estimated) suspect rate among unauthorized immigrants used to be lower than among authorized immigrants, it eventually surpassed the suspect rate among first-generation legal migrants, mostly as a result of an increase in ID fraud, property crime and drug crimes $[9,17]$. The interviews, too, demonstrate that although the men usually tried to abstain from crime as much as possible, the forces that pressured them into certain crimes were sometimes stronger than the forces discouraging offending.

\section{Selective status allocation and criminalization}

The second perspective, which we propose to call the social constructionism perspective, holds that the relationship between civic status and crime is mainly the result of social sorting and selective criminalization by the state. The state allocates civic statuses in such ways that those who (are believed to) have elevated risks of committing crimes have the highest chances of finding themselves at the bottom of the civic hierarchy. Furthermore, the behavior of those with an unprivileged civic status is most likely to be defined as 'criminal'. Three related mechanisms may play a role.

First, there is an explicit tendency in immigration law to prevent 'criminal' migrants from obtaining, or keeping, the higher civic statuses (hereafter called: 'manifest selective status allocation'). This implies a kind of reverse causation, as real or perceived differences in past offending lead to differences in civic status rather than the other way around (see Fig. 1b). For example, article $1 \mathrm{~F}$ of the Geneva Convention stipulates that 'the provisions of the Convention shall not apply to any person with respect to whom there are serious reasons for considering that he has committed a crime against peace, a war crime, a crime against humanity, or has committed a serious non-political crime outside the country of refuge prior to his admission to that country as a refugee'. Immigration law furthermore allows for crimes committed in The Netherlands to be treated as a contraindication for granting asylum. ${ }^{4}$ Moreover, in The Netherlands, all admitted asylum seekers are initially given a residence permit for five years. If the holder is sentenced for certain crimes, the permit can be withdrawn. Naturalization requires a (relatively) clean record of offences for four years.

Second, even when the screening and exclusion of 'criminals' is not an explicit goal of status allocation decisions, persons with characteristics that make offending more likely may have higher chances of being rejected (hereafter called: 'latent selective status allocation'). For example, Mascini and Van Bochove [20] show that male and single claimants have lower success rates in the Dutch asylum procedure, which they attribute to stereotyping in admission decisions: 'although single male applicants may be seen as the prototypical political refugee, they also match the image of a criminal or a "bogus" refugee' ([20], p. 119). Similar gender and age effects have recently been found in asylum admission decisions in Europe at large [37]. Such forms of social sorting may promote a spurious relationship between civic status and crime, as unaccompanied males, who have elevated chances of ending up in a disadvantaged civic status, are more likely to commit crimes than accompanied males and females (see Fig. 1c). The data allowed us to control for the following migrant characteristics: family status, sex, age, and country of origin. Such possible biases in admission decisions are consistent with Lockwood's notion of civic deficit, which was explained in the section 'Civic

\footnotetext{
$\overline{{ }^{4} \text { Vreemdelingenwet 2000, Article }} 31.2$.
} 
Stratification and the Dutch Asylum Procedure': rejected claimants may formally have been entitled to a residence permit, but lacked the moral resources to access their rights ("they matched the image of a criminal or "bogus" refugee'). It may also be that single claimants simply meet the admission requirements less often than couples and families, in which case Lockwood's category of 'civic exclusion' would be more appropriate.

Third, there may be a question of selective criminalization, which can be conceptualized as a kind of interaction effect (see Fig. 1d). Here, certain behavior - such as continued stay in a country - only becomes defined as a crime for certain categories of immigrants at the bottom of the civic hierarchy. In The Netherlands, illegal residence as such is not a crime, but Dutch law makes it possible to declare certain categories of migrants an 'undesirable alien'. Continued stay then becomes illegal - undesirable aliens are unauthorized immigrants by definition - and punishable as a public order crime (with six months' imprisonment for each violation). Naturalized citizens cannot become undesired aliens, and the conditions under which such declarations are possible are stricter for immigrants with legal stay than for unauthorized immigrants. ${ }^{5}$

\section{Hypotheses}

The following hypothesis is implied in both the first and second theoretical perspective:

H1. Among naturalized asylum migrants and residence permit holders, the documented crime rate is lower than among asylum migrants in the procedure, which in turn is lower than the documented crime rate among those who have become unauthorized immigrants.

According to the behavioral perspective, this is due to differential exposure to strain. According to the social constructionist perspective this is due to selective status allocation and criminalization. The following hypothesis is implied in the first perspective, but not the second:

H2. The relationship between, on the one hand, civic status and, on the other hand, (a) property crime, (b) ID fraud and (c) drug offences is stronger than the relationship between civic status and other crimes, such as violence.

The second perspective does not predict this relationship as selective status allocation is, in principle, insensitive to the type of crime committed. Somebody may obtain or keep a restricted civic status because of a property crime, as well as for other crimes. We conceptualize ID fraud as a behavioral adaptation to strain; unauthorized immigrants in particular are pressured into such offences in order to pass as 'legal' during ID checks, or to obtain access to the labor market by working with somebody else's papers. We nonetheless recognize that there is an

\footnotetext{
${ }^{5}$ Such resolutions require that the individual has committed a crime for which three or more years of imprisonment can be imposed, has repeatedly committed less serious crimes, or has at least two apprehensions for illegal residence. Since 2012, such resolutions have largely been replaced by 'entry bans' (see endnote 15).
} 
element of selective criminalization in such forms of fraud, and therefore also conducted analyses for specific types of crimes to see whether the effects of civic status on offending are mostly due to differences in ID fraud, or are broader. first:

The following three hypotheses are implied in the second perspective, but not the

H3. Among naturalized asylum migrants, the documented crime rate is lower than among residence permit holders.

Note that the first (behavioral) perspective does not predict this difference, as Dutch law attaches similar social and economic rights to these two statuses. Furthermore, if the association between civic status and crime is merely the result of manifest selective status allocation and selective criminalization, one would expect that:

H4. The effects of civic status on crime disappear when we control for a dummy indicating whether the asylum migrant been declared an 'undesirable alien' and/or whether the asylum claim has been rejected, at least in part, because of public safety considerations.

Finally, if the association between civic status and crime is merely due to latent selective status allocation, we should find:

H5. The effects of civic status on crime disappear when migrant characteristics are controlled that are both associated to civic status and to crime (including sex, age, family status, and national origin).

\section{Data and method}

\section{Data sources}

The hypotheses were tested using a unique dataset that was constructed in 2005 as part of a large research project for the Dutch Police \& Science Program. Data from the following four administrative sources were combined.

\section{The Immigration and Naturalization Service Information System (INDIS)}

This database contains data on all individuals who applied for asylum in The Netherlands. An extract was made available that includes all persons who (1) applied for asylum between 1995 (the first year for which reliable digital data were available) up to and including 2004, and (2) were at least 12 years of age on 1 January 2005. A total of 235,424 migrants satisfied both criteria. Most analyses, however, only pertain to those who applied for asylum before $2004(N=231,010)$, as we are primarily interested in comparing individuals who were in the country during the whole of 2004 and therefore had equal opportunity in terms of time, to become a 2004 crime suspect. Additionally, by focusing on pre-2004 applicants it is certain that the crimes followed the asylum application (the precise dates of the 
crimes were not made available), This prevents the suspect rate among asylum seekers in the procedure and unauthorized migrants from being due to asylum applications being submitted by crime suspects (it sometimes happens that unauthorized immigrants who come to the attention of the authorities, possibly as a result of crimes, apply for asylum in order to avert or postpone deportation). The data include information on the applicant's age, sex, country of birth, and whether or not the individual lived in a regular family in $2004 .^{6}$ The data also indicate whether or not the asylum request had been turned down, and whether this was (in part) because of known or suspected crimes committed in the country of origin or The Netherlands, and whether individuals had been declared an undesirable alien at some point.

\section{The Basis Service Aliens (BVV)}

Information about the active civic status on 1 February 2005 of the 231,010 migrants who had applied for asylum in the years 1995 up to and including 2003 was obtained from BVV, a database in which the Dutch authorities register all known non-citizens, which is continually updated with regard to changes in civic status. It turned out that 105,986 persons who had applied for asylum before 2004, had legal stay on 1 February 2005: 24,091 had become naturalized citizens, 49,093 had a valid residence permit, and 32,802 were still in the procedure $(690$ turned out to be deceased). The remainder (124,334) had exhausted all legal means. They were considered unauthorized immigrants to the extent they were still be in the country.

\section{The Recognition Service System (HKS)}

Information about offending was obtained from 'HKS', a system used by the Dutch police to register suspects of felonies, i.e., relatively serious offences punishable by at least 6 months of imprisonment. Crimes were categorized into seven main categories: property crimes, ID fraud, violence (including sexual violence), public order crimes, traffic crimes, drug crimes, and other crimes. In the analysis, we only look at suspects of crimes committed in 2004.

What are called Vreemdelingennummers ('Foreigner Identification Numbers'), which the Dutch government uses to identify foreigners, were not being registered in HKS, and we therefore had to devise other ways of matching asylum migrants with crime suspects. As a first matching variable we used what are called 'GBA numbers', i.e., identification numbers from the population register. These numbers are normally registered in HKS and are given to all persons who register at the municipality in the Register of Births, Deaths and Marriages. In The Netherlands, registering with the municipality is possible for asylum seekers who have been in the procedure for a number of months, and becomes mandatory for those obtaining a residence permit. Unauthorized immigrants cannot register, but many

\footnotetext{
${ }^{6}$ If the applicant was an adult, we checked whether there was at least one other adult with the same file number present in INDIS; if the applicant was a minor, we checked whether there were at least two adults with the same file number.
} 
possessed a GBA number from the period that they had legal stay. (We obtained the appropriate GBA numbers from the BVV). If persons could not be matched on the basis of their GBA number, we tried to identify them using what the Dutch police call a 'keno key', which is a combination of letters and numbers from identifiable variables such as date of birth, sex, name, and so on. ${ }^{7}$ The results were randomly checked. Of all matches, $69 \%$ were matched on GBA number. As could be expected, this percentage correlated with civic status, from $98 \%$ of the matches among the naturalized immigrants down to $49 \%$ of the matches among those with unauthorized status. ${ }^{8}$

\section{The Aliens Administration System (VAS)}

In order to calculate the percentage of unauthorized immigrants with an asylum background suspected of a crime committed in 2004, we had to establish the denominator by estimating the total number of individuals still residing in the country during 2004 among the 124,334 individuals who had applied for asylum before 2004 and no longer had legal stay by 1 February 2005. In The Netherlands, estimations of the unauthorized population are based on the VAS (renamed PSHV), an administrative database documenting all apprehensions involving unauthorized immigrants. The apprehensions are for crimes but also for illegal labor, illegal residence, and common misdemeanors. Statistically, if it is known how many unauthorized immigrants were apprehended once, twice or more often in a certain time span, it is possible to estimate how many migrants were apprehended 0 times; theoretically, the distribution of apprehensions then follows the shape of a Poisson distribution (for a detailed explanation of this method and its assumptions, see [38]). In 2002, 17,877 unauthorized migrants were apprehended, and it was estimated that there were 212,000 undocumented migrants in The Netherlands in that year ([39], p. 38-39). Thus, according to these estimations, the police apprehended about one in twelve undocumented migrants present.

The estimate does not specify what share of the unauthorized population had a background as asylum seeker. However, using the 'foreigner identification numbers', we counted the number of asylum seekers who had applied for asylum before 2004, no longer had legal stay by 1 February 2005, and were apprehended as unauthorized immigrant in 2002. This led to 2074 persons being matched. Then, based on the assumption that one in twelve unauthorized migrants were apprehended, we estimated the number of unauthorized asylum migrants who had

\footnotetext{
${ }^{7}$ We used four different keys: (1) first four characters of the surname, followed by first character of the name, and full date of birth, and (2) first four characters of the surname, followed by first character of the name and year of birth, (3) first four characters of the surname, followed by first character of place of birth and full date of birth, (4) first four characters of the surname, followed by first character of place of birth and year of birth. We also matched on these keno keys after flipping surname and name.

${ }^{8}$ Should the suspect rates at the bottom of the civic hierarchy be biased upwards due to many 'false positives' (as a consequence of different individuals happening to have the same key) there would be a risk of incorrectly accepting hypothesis 1 . However, we are quite confident that such a bias did not occur. For if the matching procedure were to produce many false positives one would expect a significant number of naturalized migrants being matched on keno number who were not being matched on GBA number. This was only the case for 13 out of $24,091(0.05 \%)$ naturalized migrants.
} 
applied for asylum before 2004 and were still in the country in 2004 to be around $24,000(2012 * 12 \approx 24,000))^{9}$

\section{Analytical strategy and descriptive statistics}

After having combined the four data sources as described, we cross-tabulated the number of crime suspects by civic status, specified by the seven crime types. Then, multivariate analyses were conducted in the form of binary logistic regression in which the dependent variable was whether one was suspected of a crime in 2004 or not. A weighting variable was calculated so that the 124,334 migrants who applied for asylum before 2004 and had exhausted all legal means by 1 February 2005 counted as 24,000 persons, i.e., the estimated number of unauthorized immigrants with an asylum background who were residing in The Netherlands in $2004 .{ }^{10}$ For lack of more specific information, it was assumed that all non-apprehended migrants in this group had an equal chance of residing illegally in The Netherlands in 2004.

Table 1 shows the descriptive statistics of the background variables used, specified by civic status. Population categories with relatively high probabilities of offending (males, singles, individuals in the age category 18-24 years or - to a lesser extent - 2244 years) turn out to be overrepresented in the lower status categories ('in procedure', 'unauthorized'). North-Africans are similarly overrepresented at the bottom of the civic hierarchy, while Asians are underrepresented. This may be due to regional differences in the formal validity of asylum claims and formal entitlement to protection (compare Lockwood's 'civic exclusion'), but it is also true that North Africans, more than other ethnic minorities, constitute a low-status group in Dutch society, to which Dutch inhabitants are relatively hostile and exclusionary (cf. [40]). North Africans - most are first and second-generation Moroccans - are also overrepresented in Dutch crime statistics, while Asians tend to be underrepresented, both in The Netherlands and elsewhere (cf. [41]). Hence, there may also be a question of 'civic deficit', meaning that North-African asylum seekers were less able to access their rights.

These systematic differences among civic statuses in terms of the demographic characteristics mentioned suggest that status allocation indeed occurs in selective ways that are likely to contribute to a higher suspect rate among those at the bottom of the civic hierarchy. In the multivariate analyses these possible composition effects will be controlled.

\section{Validity}

Evidently, the estimate of the total unauthorized population with a background as asylum seeker $(N=24,000)$ should be taken with some caution. However, we could check its validity in two ways. Firstly, we calculated conservative suspect rates for 'recent' unauthorized immigrants, namely who had applied for asylum in

\footnotetext{
${ }^{9}$ Those applying for asylum in $2003(N=4274)$ could not be matched in this way. By using the figure of 24,000 we are assuming that the number of persons leaving the unauthorized population after 2002 was equal to the number of persons entering it.

${ }^{10}$ The 2136 unauthorized immigrants who were crime suspects in 2004 (see Table 2) counted as 1 . All other rejected asylum seekers $(124,334-2136=124,009)$ counted for $0.176((24,000-2136) / 124,009 \approx 0.176)$ as we could not assess whether or not they were in the country in 2004.
} 
Table 1 Migrant characteristics by civic status. Pre-2004 applicants

\begin{tabular}{|c|c|c|c|c|}
\hline & $\begin{array}{l}\text { Naturalized } \\
(N=24,091)\end{array}$ & $\begin{array}{l}\text { Residence Permit } \\
(N=48,931)\end{array}$ & $\begin{array}{l}\text { In procedure } \\
(N=32,778)\end{array}$ & $\begin{array}{l}\text { Unauthorized } \\
(\mathrm{N}=24,000)\end{array}$ \\
\hline \multicolumn{5}{|l|}{ Sex: } \\
\hline Male & $59 \%$ & $61 \%$ & $63 \%$ & $73 \%$ \\
\hline Female & $41 \%$ & $39 \%$ & $37 \%$ & $27 \%$ \\
\hline \multicolumn{5}{|l|}{ Age: } \\
\hline $12-17$ yrs. & $16 \%$ & $13 \%$ & $14 \%$ & $7 \%$ \\
\hline $18-24$ yrs. & $19 \%$ & $26 \%$ & $29 \%$ & $23 \%$ \\
\hline $25-44$ yrs. & $49 \%$ & $46 \%$ & $47 \%$ & $60 \%$ \\
\hline $45+$ yrs. & $16 \%$ & $15 \%$ & $11 \%$ & $10 \%$ \\
\hline \multicolumn{5}{|l|}{ Family status: } \\
\hline With partner or two parents & $43 \%$ & $34 \%$ & $29 \%$ & $21 \%$ \\
\hline Single applicant or with one parent & $57 \%$ & $46 \%$ & $71 \%$ & $79 \%$ \\
\hline \multicolumn{5}{|l|}{ Region of origin ${ }^{\mathrm{a}}$ : } \\
\hline Asia & $67 \%$ & $49 \%$ & $39 \%$ & $39 \%$ \\
\hline Eastern Europe & $14 \%$ & $22 \%$ & $25 \%$ & $27 \%$ \\
\hline North Africa & $1 \%$ & $1 \%$ & $1 \%$ & $4 \%$ \\
\hline Africa other & $18 \%$ & $28 \%$ & $35 \%$ & $31 \%$ \\
\hline
\end{tabular}

${ }^{\mathrm{a}}$ Individuals from other regions (Western Europe, Latin America, et cetera) were excluded because of low numbers

2004 and had exhausted all legal remedies by February $2005(N=2139)$. For this category, we simply divided the number of crime suspects (specified by month of the asylum application) by the total number of individuals (specified by month of the asylum application). In other words, we made the conservative assumption that all these individuals, including those without police contacts, had been in the country throughout 2004 as unauthorized immigrants (even if they all had legal stay as asylum seeker for at least part of the year and even if part of them will have entered midway 2004 and/or left the country before January 2005). A comparison between these conservative suspect rates and the estimated suspect rate for the category of unauthorized migrants indicated that the population estimate is unlikely to be highly off the mark, and may actually be too high, thereby reducing the chances of an incorrect acceptance of hypothesis 1 (see the next section for details). Secondly, the estimate was compared to an amnesty program for unauthorized migrants with a background as asylum seeker, which was carried out in 2008. As part of that program, 24,377 rejected asylum seekers (ages 10 and older) were regularized [42], indicating that the estimate is unlikely to be highly inaccurate.

Some caution is also in order when interpreting police data as an indicator of crime involvement. Police data is incomplete (there is a substantial 'dark number') and sensitive to certain biases, which may include ethnic selectivity among police. 
Dutch criminologists agree that factors such as age structure, socio-economic deprivation, low informal social control and-in more controversial readingscultural factors are primarily responsible for the substantial overrepresentation of certain ethnic minorities in crime, not ethnic selectivity among police (for an overview see, [8]). There are no recent Dutch studies on ethnic selectivity (see [43]), but in a review of older studies, Junger-Tas ([44], p. 292), concluded that there is limited evidence for selectivity among police and that "differential stopand-search procedures did not result in greater arrests of minority members compared to Dutch citizens". In any event, ethnic selectivity is less of a methodological concern here. Contrary to a significant part of the existing (quantitative) studies in the field of migration and crime (see for example [41, 45-52]) we do not compare immigrants with non-immigrants, nor are we primarily interested in understanding differences in crime among different ethnic minorities (we only use national origin as a control variable). There is nonetheless a possibility that the police focused more on unauthorized immigrants and asylum seekers in the procedure than on naturalized citizens and residence permit holders. (On the tendency of police to focus on relatively marginal groups, see [53].)

\section{Findings}

\section{Bivariate analyses}

Table 2 presents suspect rates for 2004 by civic status on 1 February 2005, specified for seven types of crime. Substantial differences between the various civic categories can be observed, from $8.9 \%$ among the estimated unauthorized population down to $2.8 \%$ among naturalized immigrants. Residence permit

Table 22004 Suspect rates by civic status for different types of crime

\begin{tabular}{lllllr}
\hline & Naturalized & Res. permit & In procedure & Unauthorized & $\gamma$ \\
\hline Population & 24,091 & 48,931 & 32,778 & $24,000^{\mathrm{a}}$ & 2136 \\
Crime Suspects & 674 & 1832 & 1734 & & -0.31 \\
Suspect rates: & & & & $5.9 \%$ & -0.40 \\
Any crime & $2.8 \%$ & $3.7 \%$ & $5.3 \%$ & $0.4 \%$ & -0.35 \\
Property crime & $0.9 \%$ & $1.4 \%$ & $2.5 \%$ & $1.5 \%$ & -0.55 \\
Drugs & $0.1 \%$ & $0.2 \%$ & $0.2 \%$ & $2.1 \%$ & -0.19 \\
ID fraud & $0.2 \%$ & $0.3 \%$ & $0.6 \%$ & $1.5 \%$ & -0.28 \\
Violence & $1.0 \%$ & $1.2 \%$ & $1.5 \%$ & $0.5 \%$ & 0.10 \\
Public order & $0.5 \%$ & $0.7 \%$ & $0.9 \%$ & $0.5 \%$ & -0.27 \\
Traffic crimes & $0.5 \%$ & $0.6 \%$ & $0.3 \%$ & & \\
Other crimes & $0.2 \%$ & $0.2 \%$ & $0.3 \%$ & & \\
\hline
\end{tabular}

\footnotetext{
${ }^{\text {a Estimation }}$

b Theft with violence is categorized under 'property crime'
} 
holders (3.7\%) and those in the procedure (5.4\%) held intermediate positions. (The suspect rate among naturalized citizens is similar to the rate among native born Dutch citizens).

As expected under hypotheses 1, the higher the civic status, the lower the suspect rate. For all types of crime combined, there is a moderately strong ordinal association between civic status and being a crime suspect or not (this has been quantified by means of the gamma statistic for ordinal associations: $\gamma=-0.31$ ). The suspect rate is significantly lower among naturalized migrants than among residence permit holders, which confirms hypothesis 3 .

As expected under hypothesis 2, the degree to which suspect rates differ by civic status depends on the type of crime: the association between civic status and crime is considerably stronger for ID fraud $(\gamma=-0.55)$, property crimes $\gamma=-0.40)$ and drug crimes $(\gamma=-0.35)$ than for violence $(\gamma=-0.19)$, public order crimes $(\gamma=-0.28)$, and the category other crimes $(\gamma=-0.27)$. Also note that differences in type of offending are especially marked when status groups with substantively different rights are compared. This constitutes additional support that the differences in offending between the two 'highest' civic statuses - naturalized migrants and residence permit holders have similar economic and social rights - are mostly due to selection effects rather than differential exposure to conditions affecting criminal behavior.

Contrary to expectations, we find that traffic crimes - consisting mostly of offences such as drunk driving and culpable accidents with casualties - are somewhat more prevalent among naturalized immigrants and permit holders than among asylum seekers in the procedure and unauthorized immigrants $(\gamma=0.10)$. The reason may be that migrants with disadvantaged civic statuses may not have a car to commit these offences. Additionally, such 'expressive' crimes neither generate income nor help create the impression of legal stay, but mostly increase deportation risks.

The question can be raised of whether the population estimate for the category of unauthorized immigrants $(N=24,000)$ could be too low, as that would bias its suspect rate upwards, possibly leading to an incorrect acceptance of hypothesis 1 . However, by calculating 'conservative' suspect rates for those who applied in 2004 and had exhausted all legal remedies by February 1st 2005, it could be established that the measured suspect rate of $8.9 \%$ is unlikely to be too high. ${ }^{11}$

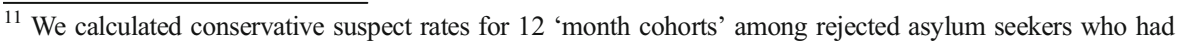
applied in 2004. These rates are based on the conservative assumption that all these applicants were in the country without legal status throughout 2004 (even if all of them had legal stay as asylum seeker for at least part of the year, and even if part of them arrived midway 2004 and/or left before January 2005). The rates vary between $6.8 \%$ and $18.6 \%$. They peak at $18.6 \%$ among those who applied for asylum in April 2004, and the $6.8 \%$ rate is found for those who applied in December 2004 while individuals in that month cohort only had a month or less to become a suspect of a crime committed in 2004, unless they were in the country before applying for asylum (we do not know the exact dates of the crimes). If we conservatively assume that this $6.8 \%$ was completely due to unauthorized migrants applying for asylum after having come to the attention of the authorities as a crime suspect, the annual suspect rate for crimes committed after the asylum application must have been $10 \%$ or more $(18.6 \%-6.8 \%)$ ), which is actually somewhat higher than the estimated rate of $8.9 \%$ presented in Table 2.
} 
Table 3 Effects (odds ratio's) of civic status and migrant characteristics on being a crime suspect in 2004

\begin{tabular}{|c|c|c|c|}
\hline & Model 1 & Model 2 & Model 3 \\
\hline Constant & 0.03 & 0.03 & 0.01 \\
\hline \multicolumn{4}{|l|}{ Civic status } \\
\hline \multicolumn{4}{|l|}{ Naturalized (ref.) } \\
\hline Residence permit & $1.35^{* *}$ & $1.34 * *$ & $1.15 * *$ \\
\hline In procedure & $1.94 * *$ & $1.85 * *$ & $1.44 * *$ \\
\hline Unauthorized & $3.39 *$ & $3.29 * *$ & $2.41 * *$ \\
\hline \multicolumn{4}{|l|}{ Control variables } \\
\hline Public safety considerations & & $3.32 * *$ & $3.23 * *$ \\
\hline Sex $($ female $=$ ref. $)$ & & & $3.61 * *$ \\
\hline \multicolumn{4}{|l|}{ Age between 12 and 17 (ref.) } \\
\hline Age between 18 and 24 & & & $1.48 * *$ \\
\hline Age between 25 and 44 & & & $0.82 * *$ \\
\hline Age $45+$ & & & $0.40 * *$ \\
\hline Lives in (unbroken) family & & & $0.84 * *$ \\
\hline \multicolumn{4}{|l|}{ Asian (incl. Turkey) (ref.) } \\
\hline Eastern European & & & $1.58 * *$ \\
\hline North African & & & $1.96 * *$ \\
\hline Sub-Saharan African & & & $1.37 * *$ \\
\hline Model $\chi^{2}$ & 1105.53 & 1306.33 & 4006.42 \\
\hline$x^{2}$ change & $1105.53 * *$ & $200.80^{* *}$ & $2697.56 * *$ \\
\hline
\end{tabular}

\section{Multivariate analyses}

Table 3 presents three logistic regression models. ${ }^{12}$ For persons registered as a crime suspect in 2004 the dependent variable is coded as 1, against 0 for persons who were not a crime suspect for that year. The unauthorized category pertains to the population estimate of 24,000 . The first model predicts the probability of being a crime suspect in 2004 by civic status only. Compared to being naturalized, having a residence permit increases the odds of being registered as a crime suspect by 1.35 , meaning that the odds of being a crime suspect was 1.35 times higher for permit holders than for naturalized immigrants. Compared to being naturalized, being 'in the procedure' and being 'unauthorized' is associated with a 1.94 and 3.39 higher odds respectively. This basically demonstrates the same as Table 2: the probability of being suspected in 2004 is lowest among naturalized immigrants and highest among unauthorized asylum seekers.

The second model tests hypothesis 4 by adding a dummy variable that assigns a 1 to all individuals whom the state explicitly wished to exclude from a residence

\footnotetext{
${ }^{12}$ Some caution is in order when comparing logistic models containing different independent variables (cf. [54]). When models predict observed values better (as is the case here), the size of coefficients tends to increase. To some extent, this masks the reduction of the coefficients of civic status after including statistical controls. Mood suggests calculating Y-standardization as a (partial) solution to this problem. That did not lead to substantively different conclusions, and we decided not to report Y-standardized coefficients.
} 
permit on the grounds of public safety considerations. This includes persons who were declared 'undesirable aliens' as well as individuals whose asylum claims were rejected on the grounds of public safety considerations. It turns out that about $1 \%(N=2495)$ of all migrants who applied for asylum in the period 19952003 satisfy one or both of these conditions. Of these, 1334 are estimated to have been residing in The Netherlands in $2004 .{ }^{13}$ Given these relatively low numbers, it is unlikely that the aforementioned forms of selective status allocation and criminalization have been very influential. The role of selective criminalization turns out to have been modest in particular, as only 113 'undesired aliens' were crime suspects in 2004, of whom only 23 were merely suspected of a public order crime (the category that includes the 'crime' of continued stay) without any other crimes. Indeed, the association between civic status and crime persists as a result of this control, leading us to reject hypothesis 4 . At the same time, the differences in suspect rates between, on the one hand, unauthorized immigrants and naturalized immigrants and, on the other hand, permit holders and naturalized migrants do become smaller. For example, the odds ratio for being an unauthorized immigrant goes down from 3.39 (model 1) to 3.29 (model 2).

Model 3 estimates the effect of civic status if the four civic status groups (naturalized, residence permit, in procedure, unauthorized) were identical in terms of sex, age, family status, and region of origin. As expected, registered offending is higher for males than for females (odds ratio =3.62), and lower for those living with a partner or two parents compared to singles or those living with one parent (odds ratio $=0.84$ ). Furthermore, there is a curvilinear relationship between age and offending, with young adults (ages 18-24) having the highest chances of being registered as a crime suspect. Finally, Asians have lower suspect rates than Africans and Eastern Europeans. This final control leads us to conclude that the more latent forms of filtering out newcomers with elevated crime risks were more influential in bringing about the association between civic status and crime than the explicit governmental efforts to socially exclude (suspected) 'criminals': the association between civic status and crime becomes substantially weaker in model 3. At the same time, the effect of civic status clearly persists, and hypothesis 5 is rejected. For example, the odds of being a crime suspect as a migrant 'in the procedure' compared to naturalized immigrants is still 1.45 , while having unauthorized status is associated with a 2.44 higher odds of being a crime suspect (for the 2004 cohort: 2.88 ).

As a final step, we examined whether similar patterns hold for different types of crimes by running the first and final model for each of the seven crimes (see Table 4; in order to save space, the coefficients of the control variables and the models' constants are not reported.) For each type of crime, civic status is a relevant predictor of being a crime suspect or not, both before and after indicators of selective status allocation and criminalization are controlled. In line with hypothesis 2 , we find that the remaining effects are the strongest for crimes that, more than other crimes, can be seen as behavioral responses to the strains of having a disadvantaged civic status.

\footnotetext{
${ }^{13}$ We assumed that those among the 2495 who were not suspected of a crime in 2004 had similar chances of being in the country in 2004 as all other individuals in our database lacking legal stay on that date (see note 10).
} 
Table 4 Effects of civic status (odds ratios) on different crimes before and after controls

\begin{tabular}{|c|c|c|}
\hline & Model 1 & Model 3 \\
\hline \multicolumn{3}{|l|}{ Property crime } \\
\hline \multicolumn{3}{|l|}{ Naturalized (ref.) } \\
\hline Residence permit & $1.51^{* *}$ & $1.26 * *$ \\
\hline In procedure & $2.75 * *$ & $1.97 * *$ \\
\hline Unauthorized & $4.83 * *$ & $3.28 * *$ \\
\hline \multicolumn{3}{|l|}{ ID fraud } \\
\hline \multicolumn{3}{|l|}{ Naturalized (ref.) } \\
\hline Residence permit & $1.66^{* *}$ & 1.29 \\
\hline In procedure & $3.55 * *$ & $2.34 * *$ \\
\hline Unauthorized & $9.43 * *$ & $6.09 * *$ \\
\hline \multicolumn{3}{|l|}{ Drugs } \\
\hline \multicolumn{3}{|l|}{ Naturalized (ref.) } \\
\hline Residence permit & $2.53 * *$ & $1.93 *$ \\
\hline In procedure & $2.55 * *$ & 1.61 \\
\hline Unauthorized & $5.95 * *$ & $2.95 * *$ \\
\hline \multicolumn{3}{|l|}{ Violence } \\
\hline \multicolumn{3}{|l|}{ Naturalized (ref.) } \\
\hline Residence permit & $1.29 * *$ & $1.18^{*}$ \\
\hline In procedure & $1.57 * *$ & $1.29 * *$ \\
\hline Unauthorized & $2.20 * *$ & $1.75^{* *}$ \\
\hline \multicolumn{3}{|l|}{ Public order } \\
\hline \multicolumn{3}{|l|}{ Naturalized (ref.) } \\
\hline Residence permit & 1.42 & 1.21 \\
\hline In procedure & $2.01 * *$ & $1.38 * *$ \\
\hline Unauthorized & 3.13 & $2.13 * *$ \\
\hline \multicolumn{3}{|l|}{ Traffic crime } \\
\hline \multicolumn{3}{|l|}{ Naturalized (ref.) } \\
\hline Residence permit & 1.21 & 1.04 \\
\hline In procedure & $0.65 * *$ & $0.49 * *$ \\
\hline Unauthorized & 0.91 & $0.58 * *$ \\
\hline \multicolumn{3}{|l|}{ Other crime } \\
\hline \multicolumn{3}{|l|}{ Naturalized (ref.) } \\
\hline Residence permit & 1.21 & 1.02 \\
\hline In procedure & $1.65 * *$ & 1.21 \\
\hline Unauthorized & $2.87^{* *}$ & $1.94 * *$ \\
\hline
\end{tabular}

Being unauthorized, for example, is still associated with a 6.09 higher odds of being suspected of ID fraud. But the effects of civic status are not limited to ID fraud: being 'in the procedure', for instance, is still associated with a 1.97 higher odds of being suspected of a property crime, and being unauthorized is still associated with a 2.95 higher odds of being a drug crime suspect. 


\section{Conclusion}

This article analytically synthesizes the available literature on the relationship between civic status and crime, and applies this integrated framework to asylum migrants in The Netherlands. Underlying the analysis is the notion of 'civic stratification'. In an effort to manage immigration, governments create complex hierarchies of legal statuses - here called: civic statuses - that are linked to specific economic, social and political rights. A central assumption behind this study is that civic stratification is relevant to understand crime patterns.

Under the system of civic stratification found in The Netherlands in 2004, naturalized immigrants and permit holders had a significantly lower probability of being registered as a crime suspect than asylum seekers in the procedure and unauthorized immigrants, and such differences were especially marked for property and drug offences, and ID fraud. These outcomes suggest that civic status influences behavior via the strain perspective, and confirm our first two hypotheses. Furthermore, the suspect rate among naturalized migrants is found to be lower than among residence permit holders, even if these categories have similar economic and social rights, leading us to accept hypothesis 2 . The association between civic status and crime also becomes weaker when indicators of selective status allocation are controlled. When we take into consideration whether or not asylum migrants were rejected because of public safety considerations, or lost their residence permit because of criminal convictions, the differences in suspect rates become smaller, although the association between civic status and crime persists, leading us to reject hypothesis 4 . The effects of civic status on crime also become smaller, but still persist, when various individual characteristics are controlled that are generally seen as risk factors for criminal behavior, leading us to reject hypothesis 5 . In spite of rejecting hypotheses 4 and 5, our main claim is nonetheless that a combination of perspectives is required in order to understand the complex relationship between civic stratification and crime. Civic stratification structures behavior, including behavior that is punishable, but civic statuses are not allocated at random (in part because the tendencies towards civic stratification in Lockwood's [2] sense will put certain groups at a disadvantage in admission decisions), and certain migration behavior is selectively criminalized.

Evidently, the findings regarding the unauthorized population need to be taken with caution, as we had to rely on statistical estimates to assess its size. However, we obtained similar results for those who applied for asylum in 2004 and had exhausted all legal remedies by February 2005, when making the conservative assumption that all individuals in this category were in the country as unauthorized immigrants throughout 2004.

We contend that strain theory is essential in order to understand the relationship between civic status and crime; it is especially useful to explain the association between civic status and property crime, ID fraud and drug crimes. We do not claim, however, that all relevant processes and mechanisms have been taken into consideration in the present analyses. Additional theoretical elaborations are possible, for example, which similarly depart from the notion that civic status influences individual behavior. For instance, the finding that migrants with the two 'lowest' civic statuses were considerably underrepresented with regard to traffic crime suggests that civic status may structure the opportunities to commit certain offences (compare [55] notion of a 'differential opportunity structure'). Likewise, differential access to employment as a 
result of civic stratification may contribute to differences in informal control. ${ }^{14}$ There is a strong current in life course criminology that argues that unemployment attenuates informal social control, which in turn increases criminal activity (cf. [56, 57]). Such theoretical elaborations are all similar to our application of strain theory in one important respect: they are varieties of what Ritzer [58] has called the social facts paradigm in sociology, as they all depart from the assumption that civic stratification is a social fact that exerts power over individual behavior. They are all varieties of the behavioral perspective.

Similarly, we may not have included in the analysis all mechanisms that are informed by a constructionist stance. Additional aspects of social sorting may play a role in status allocation decisions, and part of the remaining effects of civic status could be due to the unobserved effects of social class, for example. The UNHRC Convention relating to the Status of Refugees defines refugees as those fleeing persecution for various reasons, including political opinion. If higher educated asylum seekers more often flee because of political activism, or when they are more successful in convincing immigration officials that they deserve protection, they will end up in higher civic statuses than lower educated asylum seekers, potentially contributing to a spurious relationship between civic status and crime. Future research could explore such additional mediating mechanisms and sorting processes, ideally by using longitudinal data, allowing researchers to examine the effects of changes in civic status on criminal behavior. Should the analysis be limited to legally staying migrants, it may also be possible to obtain direct measurements of relevant mechanisms via a survey.

A final point of discussion relates to the generalizability of our outcomes. The first question is its generalizability in time. As we use data from the period 1995-2004, one could ask whether our findings still apply today. Is a low civic status still associated with a higher propensity of criminal activity? Does criminal behavior still limit the changes of migrants obtaining a higher civic status? We would argue that our findings are likely to still hold as the Dutch system of civic stratification has not changed fundamentally. For example, the policies limiting asylum seekers' and unauthorized immigrants' access to the labor market and social provisions are still in place. In fact, paying attention to civic stratification has probably become even more important than it already was: tendencies to selectively criminalize and exclude 'unwanted' immigrants both unauthorized immigrants and residence permit holders with a criminal record have become stronger in the post 2004 period, as they have elsewhere in Europe and the United States (cf. [59, 60]). ${ }^{15}$

\footnotetext{
$\overline{14}$ Only residence permit holders and naturalized migrants are entitled to family reunification. Hence part of the effect of family status on crime could be seen as an indirect effect of civic status via the mediating mechanism 'informal social control'. We decided to treat family status as a confounding factor in relation to selective status allocation because $79 \%$ of those who lived in a family in 2004 had applied on the same day, and had not reunified at a later stage.

${ }^{15}$ For example, after implementing the 2008 EU Return Directive in 2011, the Dutch government began to systematically impose 'entry bans' on apprehended unauthorized immigrants. The Netherlands chose to criminalize continued residence while such a ban is in force as a misdemeanour (or a felony if the person received the ban due to a criminal record), which is punishable by a maximum of six months of detention or a fine of up to $€ 3900$ ( $€ 7800$ in case of an entry ban because of a criminal record). In 2012 it was also made easier to terminate the residence permit of non-citizens who have been convicted of certain crimes. The most important change was that resident permit holders with relatively short residence durations also became at risk of losing their losing the permit in case of relatively minor crimes [17].
} 
While the importance of selective status allocation and criminalization has probably increased, the influence of strain may have diminished to some extent. Asylum seekers in the procedure may now work 24 instead of 12 weeks a year, and the Dutch government has also been successful in shortening the asylum procedure, thereby limiting the time asylum seekers live under deprived conditions in reception centers (the 2015 'refugee crisis' changed this again due to capacity problems). Additionally, since 2011, unauthorized families with children under the age of 18 have a right to an elementary 'bed, bath and bread' arrangement in what are called Family Locations (Gezinslocaties), which now accommodate about 2000 persons (the families have to report regularly to the immigration authorities and are still at risk of being deported) [31]. In the near future, the pressure to offend may similarly diminish to some extent for unauthorized immigrants without children: in November 2014, the European Committee of Social Rights (ECSR) decided that The Netherlands should grant all unauthorized immigrants a right to basic (night) shelter. ${ }^{16}$

The other question is whether the Dutch case is generalizable to other countries. For two reasons, we think that this is generally the case. First, The Netherlands is not an extraordinary case since all Western countries regulate immigration by applying different social, economic and residence rights to immigrants who are more or less welcome - with more or less comparable systems of civic stratification as a result. Second, there actually seems to have been a certain shift in the direction of the Dutch case; for instance, both in Europe and the USA, there has been a tendency toward stricter policy approaches to unauthorized migrants, which include stepped-up efforts to exclude the latter from labor markets, social provisions, and housing [9, 12, 17, 61-65].

This is not to say, of course, that there will not be significant differences between countries. In less comprehensive welfare states, such as the United States, a 'high' civic status will bring fewer social rights than in The Netherlands, and may be less of a real privilege. There will also be countries with more work opportunities in the informal sector cushioning the potential negative consequences of being accorded a 'low' civic status. ${ }^{17}$ In such contexts, there will be smaller differences between civic status categories than in The Netherlands, which combines more advanced social protection systems with a relatively small informal economy, thus leaving fewer opportunities to compensate for a lower civic status with informal work, and amplifying the potential behavioral effects of civic stratification. Finally, there is variation in the degree to which migrants with weaker civic statuses are incorporated by established ethnic communities, thereby protecting the former from the most extreme forms of marginality. Compared to Europe, the United States has low levels of asylum seekers. Most of its unauthorized immigrants are not former asylum seekers, but labour or family migrants, most of whom - about $60 \%$ (cf. [67]) - are estimated to be from Mexico, which has been a major source country of immigration to the US for a long time.

\section{In conclusion}

In several European countries, as well as in Australia and the United States, there have been media reports about crime and other forms of assumed deviance among asylum

\footnotetext{
$\overline{{ }^{16} \text { See complaint number 90/2013 }}$, Conference of European Churches versus The Netherlands. In 2015, the government decided to facilitate six night shelters spread across the country. Access depends on the condition that unauthorized migrants 'cooperate' with their departure.

${ }^{17}$ The estimated relative size of the informal sector in The Netherlands is somewhat larger than in United States, but smaller than in countries like Spain and Italy [66].
} 
migrants and unauthorized immigrants, which have been used by politicians to argue for more restrictive admission policies (cf. [68-70]). The present analysis shows that an opposite logic could also be followed: it suggests that social exclusion actually contributes to certain crime issues, and that the chances of such issues occurring decrease when asylum migrants are more fully integrated, i.e., given similar rights as citizens, rather than being excluded. This message is especially important in a time when asylum applications are again on the rise in most countries of the Global North. While a certain degree of civic stratification is inevitable, especially in a global order that is marked by considerable international inequality, this does not take away the obligation on the part of states to invest in good and fair asylum procedures (thus reducing the number of asylum seekers who have good reasons to overstay a rejection), and to guarantee certain minimum rights for those at the bottom of the civic hierarchy. Seen in that light, decisions such as by the ECSR seem to represent a welcoming counterforce against civic stratification pushed too far.

Open Access This article is distributed under the terms of the Creative Commons Attribution 4.0 International License (http://creativecommons.org/licenses/by/4.0/), which permits unrestricted use, distribution, and reproduction in any medium, provided you give appropriate credit to the original author(s) and the source, provide a link to the Creative Commons license, and indicate if changes were made.

\section{References}

1. Kofman, E. (2001). Contemporary European migrations, civic stratification and citizenship. Political Geography, 21(8), 1035-1054. https://doi.org/10.1016/S0962-6298(02)00085-9.

2. Lockwood, D. (1996). Civic integration and class formation. The British Journal of Sociology, 47(3), 531-550. https://doi.org/10.2307/591369.

3. Morris, L. (2002). 'Managing migration: Civic stratification and migrants' rights. London: Routledge.

4. Morris, L. (2003). 'Managing contradiction: civic stratification and migrants' rights. International Migration Review, 37(1), 74-100.

5. Morris, L. (2010). Asylum, welfare and the cosmopolitan ideal: A sociology of rights. London: Routledge.

6. Alt, J. (1999). Illegal in Deutschland. Forschungsproject zur Lebenssituation 'illegaler' Migranten in Leipzig. Kalsruhe: Von-Loeper Literaturverlag.

7. Althoff, M., De Haan, W., \& Miedema, S. (2006). Criminaliteitspatronen en carrières van asielzoekers. Apeldoorn: Police and Science.

8. Engbersen, G., Van der Leun, J., \& De Boom, J. (2007). The fragmentation of migration and crime in the Netherlands. Crime and Justice, 35, 389-452.

9. Leerkes, A., Engbersen, G., \& Van der Leun, J. (2012a). Crime among irregular immigrants and the influence of internal border control. Crime, Law and Social Change, 12(1), 15-38.

10. McDonald, W. F. (1997). Illegal immigration: Crime, ramifications and control (the American experience). In W. F. McDonald (Ed.), Crime and law enforcement in the global village (pp. 65-86). Cincinnati: Anderson Publishing Company.

11. Van der Woude, M. A. H., Van der Leun, J. P., \& Nijland, J. A. (2014). Crimmigration in the Netherlands. Law \& Social Inquiry, 39(3), 560-579. https://doi.org/10.1111/lsi.12078.

12. Wilson, D. (2015). Marginalizing migrants. Illegality, racialization, and vulnerability. In E. Goode (Ed.), The handbook of deviance (pp. 504-520). Hoboken: Wiley.

13. Bigo, D. (2004). 'Criminalization of migrants': The side effect of the will to control the frontiers and the sovereign illusion. In B. Bogusz, R. Cholewinski, A. Cygan, \& E. Szyszczak (Eds.), Irregular migration and human rights: Theoretical, European and International Perspectives (pp. 90-127). Leiden: Marinus Nijhof Publishers.

14. Bosworth, M., \& Guild, M. (2008). Governing through migration control. Security and citizenship in Britain. British Journal of Criminology, 48(6), 703-719. https://doi.org/10.1093/bjc/azn059.

15. Dowling, J. A., \& Inda, J. X. (Eds.). (2012). Governing immigration through crime. A reader. Redwood City: Stanford University Press.

16. Kanstroom, D. (2004). Criminalizing the undocumented: Ironic boundaries of the post-September 11th 'Pale of Law'. North Carolina Journal of International Law and Commercial Regulation, 29, 639-670. 
17. Leerkes, A., Van der Leun, J., \& Engbersen, G. (2012b). Crime among irregular immigrants and the influence of crimmigration processes. In M. Guia, J. Van der Leun, \& M. Van der Woude (Eds.), Social control and justice: Crimmigration in the age of fear (pp. 267-288). The Hague: Eleven International Publishers.

18. Stumpf, J. P. (2006). The crimmigration crisis: immigrants, crime, and sovereign power. The American University Law Review, 56(2), 367-419.

19. Welch, M. (2003). Ironies of social control and the criminalization of immigrants. Crime, Law and Social Change, 39(4), 319-337.

20. Mascini, P., \& Van Bochove, M. (2009). Gender stereotyping in the Dutch asylum procedure: 'Independent' men versus 'dependent' women. International Migration Review, 43(1), 112-133. https://doi.org/10.1111/j.0197-9183.2008.01149.x.

21. De Boom, J., Engbersen, G., \& Leerkes, A. (2006). Asielmigratie en criminaliteit. Den Haag: Elvevier.

22. Engbersen, G., Leerkes, A., \& Snel, E. (2014). Ethnicity, crime and immigration in the Netherlands. In S. Bucerius \& M. Tonry (Eds.), The Oxford handbook of ethnicity, crime, and immigration (pp. 766-790). Oxford: Oxford University Press.

23. Hollifield, J. F. (2004). The emerging migration state. International Migration Review, 38(3), 885-912. https://doi.org/10.1111/j.1747-7379.2004.tb00223.x.

24. Menjívar, C. (2006). Liminal legality: 'Salvadoran and Guatemalan immigrants' lives in the United States. American Journal of Sociology, 111(4), 999-1037.

25. Bean, F. D., Leach, M. A., Brown, S. K., Bachmeier, J. D., \& Hipp, J. R. (2011). The educational legacy of unauthorized migration: Comparisons across U.S.-'immigrant groups in how parents' status affects their offspring. International Migration Review, 45(2), 348-385. https://doi.org/10.1111/j.17477379.2011.00851.x.

26. Beckett, K., \& Evans, H. (2015). Crimmigration at the local level: criminal justice processes in the shadow of deportation. Law \& Society Review, 49(1), 241-227. https://doi.org/10.1111/lasr.12120.

27. Snel, E., Faber, M., \& Engbersen, G. (2015). Civic stratification and social positioning: CEE labour migrants without a work permit. Population, Space and Place, 21(6), 518-534.

28. Dourleijn, E., \& Dagevos, J. (Eds.). (2011). Vluchtelingengroepen in Nederland. Over de integratie van Afghaanse, Iraakse, Iraanse en Somalische migranten. The Hague: SCP.

29. Engbersen, G., Dagevos, J., Jennissen, R., Bakker, L., \& Leerkes, A. (2016). No time to lose: From reception to integration of asylum migrants. The Hague: Wetenschappelijke Raad voor het Regeringsbeleid, Sociaal-Cultureel Planbureau, Wetenschappelijk Onderzoek en Documentatiecentrum.

30. Laban, C. J., Komproe, I. H., Gernaat, H. B., \& De Jong, J. T. (2008). The impact of a long asylum procedure on quality of life, disability and physical health in Iraqi asylum seekers in the Netherlands. Social Psychiatry and Psychiatric Epidemiology, 43(7), 507-515. https://doi. org/10.1007/s00127-008-0333-1.

31. Leerkes, A. (2016). Back to the poorhouse? Social protection and social control of unauthorized immigrants in the shadow of the welfare state. Journal of European Social Policy, 26(2), 140-154.

32. Leerkes, A. (2009). Illegal residence and public safety in the Netherlands. Amsterdam: Amsterdam University Press.

33. Van der Leun, J., \& Kloosterman, R. (2006). Going underground. The labor market position of undocumented immigrants in the Netherlands. Tijdschrift voor Economische en Sociale Geografie, 97(1), 59-68. https://doi.org/10.1111/j.1467-9663.2006.00496.x.

34. Agnew, R. (2001). Building on the foundation of general strain theory: specifying the types of strain most likely to lead to crime and delinquency. Journal of Research in Crime and Delinquency, 38(4), 319-361. https://doi.org/10.1177/0022427801038004001.

35. Merton, R. K. (1957). Social theory and social structure. New York: Free Press.

36. Abrego, L. J. (2011). Legal consciousness of undocumented Latinos: fear and stigma as barriers to claims-making for first- and 1.5-generation immigrants. Law \& Society Review, 45(2), 337-370. https://doi.org/10.1111/j.1540-5893.2011.00435.x.

37. Leerkes, A. (2015). How (un)restrictive are we? 'Adjusted' and 'expected' asylum recognition rates in Europe. The Hague: WODC.

38. Van der Heijden, P. G. M., Cruijff, M., \& Van Houwelingen, H. C. (2003). Estimating the size of a criminal population from police records using the truncated poisson regression model. Statistica Neerlandica, 57(3), 289-304. https://doi.org/10.1111/1467-9574.00232.

39. Leerkes, A., Van San, M., Engbersen, G., Cruijff, M., \& Van der Heijden, P. (2004). Wijken voor illegalen. Over ruimtelijke spreiding, huisvesting en leefbaarheid. The Hague: SdU.

40. Sniderman, P. M., Hagendoorn, L., \& Prior, M. (2004). Predisposing factors and situational triggers: exclusionary reactions to immigrant minorities. American Political Science Review, 98(1), 35-49. 
41. Bucerius, S., \& Tonry, M. (Eds.). (2014). The Oxford handbook of ethnicity, crime, and immigration. Oxford: Oxford University Press.

42. Wijkhuijs, V., Iloway, A. M., Kromhout, M. H. C., Welle, I. C., \& Van der Smit, M. (2012). Pardon? Evaluatie van de regeling afwikkeling nalatenschap oude Vreemdelingenwet. The Hague: WODC.

43. Van der Leun, J. P., \& Van Der Woude, M. (2011). Ethnic profiling in the Netherlands? A reflection on expanding preventive powers, ethnic profiling and a changing social and political context. Policing and Society, 21(4), 444 455. https://doi.org/10.1080/10439463.2011.610194.

44. Junger-Tas, J. (1997). Ethnic minorities and criminal justice in the Netherlands. Crime and Justice, 21, 257-310.

45. Bell, B., Fasani, F., \& Machin, S. (2013). Crime and immigration: evidence from large immigrant waves. The Review of Economics and Statistics, 95, 1278-1290.

46. Blom, M., \& Jennissen, R. (2014). The involvement of different ethnic groups in various types of crime in the Netherlands. European Journal on Criminal Policy and Research, 20(1), 51-72. https://doi. org/10.1007/s10610-013-9210-x.

47. Hagan, J., \& Palloni, A. (1999). Sociological criminology and the mythology of Hispanic immigration and crime. Social Problems, 46(4), 617-632. https://doi.org/10.2307/3097078.

48. Lee, M. T., Martinez, R., \& Rosenfeld, R. (2001). Does immigration increase homicide? Negative evidence from three border cities. The Sociological Quarterly, 42(4), 559-580. https://doi.org/10.1111 j.1533-8525.2001.tb01780.x.

49. Lynch, J. P., \& Simon, R. J. (1999). A comparative assessment of criminal involvement among immigrants and natives across seven nations. International Criminal Justice Review, 9(1), 1-17. https://doi.org/10.1177/105756779900900101.

50. Martinez, R., Iwama, J. A., \& Stowell, J. I. (2015). Race, immigration, and homicide in contemporary Europe and the United States: an urban comparison. Crime Law \& Social Change, 64(4), 291-304. https://doi.org/10.1007/s10611-015-9591-5.

51. Mohn, S., \& Ellingsen, D. (2016). Unregistered residents and registered crime: an estimate for asylum seekers and irregular migrants in Norway. Journal of Scandinavian Studies in Criminology and Crime Prevention, 17(2), 166-176.

52. Tonry, M. (Ed.). (1997). Ethnicity, crime and immigration: Comparative and cross-national perspectives. Chicago: University of Chicago Press.

53. Newburn, T. (Ed.). (2012). Handbook of policing. London: Routledge.

54. Mood, C. (2010). Logistic regression: why we cannot do what we think we can do, and what we can do about it. European Sociological Review, 26(1), 67-82. https://doi.org/10.1093/esr/jcp006.

55. Cloward, R. A., \& Ohlin, L. E. (1960). Delinquency and opportunity structures: A theory of delinquent gangs. New York: The Free Press.

56. Laub, J. H., \& Sampson, R. J. (2003). Shared beginnings, divergent lives: Delinquent boys to age 70. Cambridge: Harvard University Press.

57. Weerman, F., \& Bijleveld, C. (2013). Criminal behaviour from school to the workplace. Untangling the complex relations between employment, education and crime. New York: Routlegde.

58. Ritzer, G. (1975). Sociology: a multiple paradigm science. The American Sociologist, 10, 156-167.

59. Aas, K. F., \& Bosworth, M. (2013). The borders of punishment migration, citizenship, and social exclusion. Oxford: Oxford University Press.

60. Guia, M. J., Van der Leun, J., \& Van der Woude, M. (Eds.). (2013). Social control and justice: Crimmigration in the age of fear. The Hague: Eleven International Publishers.

61. Düvell, F. (Ed.). (2006). Illegal immigration in Europe. Beyond control? Houndsmills: Palgrave MacMillan.

62. Kobach, K. W. (2008). Attrition through enforcement: a rational approach to illegal immigration. Tulsa Journal of Comparative \& International Law, 15, 155-163.

63. Leerkes, A., Bachmeier, J., \& Leach, M. (2013). When the border is 'everywhere': State-level variation in migration control and changing settlement patterns of the unauthorized immigrant population in the United States. International Migration Review, 47(4), 910-943.

64. Newman, B. J., Johnston, C. D., Strickland, A. A., \& Citrin, J. (2012). Immigration crackdown in the American workplace. Explaining variation in e-verify policy adoption across the U.S. States. State Politics \& Policy Quarterly, 12(2), 160-182. https://doi.org/10.1177/1532440012442910.

65. Triandafyllidou, A. (Ed.). (2010). Irregular migration in Europe. Myths and realities. Burlington: Ashgate.

66. Schneider, F., Buehn, A., \& Montenegro, C. (2010). Shadow economies all over the world: New estimates for 162 countries from 1999 to 2007. New York: World Bank.

67. Passel, J. S., \& Cohn, D. (2011). Unauthorized immigrant population: National and state trends, 2010. Pew Hispanic Center: Washington D.C. 
68. Baker, P., \& McEnery, T. (2005). A corpus-based approach to discourses of refugees and asylum seekers in UN and newspaper texts. Journal of Language \& Politics, 4(2), 197-226. https://doi.org/10.1075 /jlp.4.2.04bak.

69. Pickering, S. (2001). Common sense and original deviancy: news discourses and asylum seekers in Australia. Journal of Refugee Studies, 14(2), 169-186. https://doi.org/10.1093/jrs/14.2.169.

70. Welch, M., \& Schuster, L. (2005). Detention of asylum seekers in the US, UK, France, Germany, and Italy: a critical view of the globalizing culture of control. Criminal Justice, 5(4), 331-355. 